tance in Streptococcus pneumoniae: an epidemiological survey in France, 1970-1990. Clin Infect Dis 1992;15:95-98.

10. Aszkenasy OM, George RC, Begg NT. Pneumococcal bacteraemia and meningitis in England and Wales, 1982 to 1992. Commun Dis Rep 1995;5:R45-R50.

11. Young SE. Bacteraemia, 1975-1980: a survey of cases reported to the PHLS Communicable Disease Surveillance Centre. J Infect 1982;5:19-26.

12. Baltimore RS. New challenges in the development of a conjugate pneumococcal vaccine. JAMA 1992;268:3366,3367.

13. Heap BJ. Notifiable diseases. BMJ 1992;304:726,727.

14. Ackman DM, Birkhead G, Flynn M. Assessment of surveillance for meningococcal disease in New York state, 1991. Am J Epidemiol 1996;144:78-82.

15. Sørensen HT, Sabroe S, Olsen J. A framework for evaluation of secondary data sources for epidemiological research. Int J Epidemiol 1996;25:435-442.

16. Iezzoni LI, Burnside S, Sickles L, Moskowitz MA, Sawitz E Levine PA. Coding of acute myocardial infarction. Clinical and policy implications. Ann Intern Med 1988;109:745-751.

17. Raiford DS, Gutthann SP, Rodriguez LAG. Positive predictive value of ICD-9 codes in the identification of cases of complicated peptic ulcer disease in the Saskatchewan Hospital Automated Database. Epidemiology 1996;7:101-104.

18. Sørensen HT, Hansen I, Ejlersen E, Schønheyder HC, Hamburger H, Sabroe S. Identification of cases meningococcal disease: data quality in two Danish population-based information systems during a 14-year period. Int J Risk Safety Med 1995;7:179-189.

19. Fonager K, Sørensen HT, Rasmussen NS, Møller-Petersen J, Vyberg M. Assessment of the diagnosis of Crohn's disease and ulcerative colitis in a Danish hospital information system. Scand J Gastroenterol 1996;31:154-159.

20. Schiff GD, Yaacoub AS. The diagnostic coding of myocardial infarction. Ann Intern Med 1989;110:243.

21. Fletcher RH, Fletcher SW, Wagner EH. Clinical Epidemiology. 3rd ed. Baltimore, MD: Williams \& Wilkins; 1996.
22. Schønheyder HC, Højbjerg T. The impact of the first notification of positive blood cultures on antibiotic therapy. A oneyear survey. APMIS 1995;103:37-44.

23. Meulengracht A, Madsen M. Registre inden for sundhedsområdet (Registers within the health sector). Copenhagen, Denmark: Danish Institute for Clinical Epidemiology; 1982.

24. World Health Organization. International Statistical Classification of Diseases and Health Related Problems. 10th ed. Geneva, Switzerland: WHO; 1992.

25. Schiøler G, Mosbech J. Klassifikation af sygdomme (International Statistical Classification of Diseases and Health Related Problems). 10th ed. Copenhagen, Denmark: Sundhedsstyrelsen and Munksgaard; 1993.

26. Weinstein MP, Reller LB, Murphy JR, Lichtenstein KA. The clinical significance of positive blood cultures: a comprehensive analysis of 500 episodes of bacteremia and fungemia in adults, I: laboratory and epidemiologic observations. Rev Infect Dis 1983;5:35-53.

27. Young LS. Sepsis syndrome. In: Mandell GL, Bennet JE, Dolin R, eds. Principles and Practice of Infectious Diseases. 4th ed. New York, NY: Churchill Livingstone; 1995.

28. Bone RC. Sepsis, the sepsis syndrome, multi-organ failure: a plea for comparable definitions. Ann Intern Med 1991;114:332,333.

29. Desenclos JC, Bijkerk H, Huisman J. Variations in national infectious diseases surveillance in Europe. Lancet 1993;341:1003-1006.

30. Arbo MD, Snydman DR. Influence of blood culture results on antibiotic choice in the treatment of bacteremia. Arch Intern Med 1994;154:2641-2645.

31. Frain JP, Frain AE, Carr PH. Experience of medical senior house officers in preparing discharge summaries. BMJ 1996;312:350.

32. Paul SM, Finelli L, Crane GL, Spitalny KC. A statewide surveillance system for antimicrobial-resistant bacteria: New Jersey. Infect Control Hosp Epidemiol 1995;16:385-390.

\title{
Staffing Ratio Has Impact on Risk of Nosocomial Infections
}

\section{Gina Pugliese, RN, MS Martin S. Favero, PhD}

Archibald and colleagues from the CDC's Hospital Infections Program, while conducting an investigation of a Serratia marcescens outbreak in a pediatric cardiac intensivecare unit (CICU), noted that understaffing or overcrowding might have been underlying risk factors. They conducted a study to assess the effect of fluctuations in CICU nurse-staffing levels and patient census on the CICU nosocomial infection rate (NIR). The monthly CICU nursing hours, patient days, and nosocomial infections were obtained from retrospective review of administrative, patient, and microbiology records during December 1994 through December 1995 (study period). The NIR and nursing hours to patient-day ratio then were calculated.
The correlations between NIR versus nursing hours, patient days, and nursing hours to patient-day ratio were determined.

The results showed that the median monthly CICU NIR was 6.9 (range, 0-15.2) infections per 1,000 patient days; the median number of hours worked per month by CICU registered nurses was 7,754 (range, $7,133-8,452)$ hours; the median number of patient days treated per month was 507 (range, 381-590) patient days; and the median monthly nursing hours to patient day ratio was 15.2 to 1 (range, 13.2:1-19.9:1). The strongest linear correlation was observed between the monthly NIR and patient days $(P=.0001)$. There was an inverse correlation between the monthly NIR and nursing hours to patient-day ratio $(P=.003)$.

The researchers concluded that the NIR was correlated most strongly with patient census but also was associated strongly with the nursing hours to patient day ratio. It is believed that these factors may influence the infection rate because of breaks in healthcare worker aseptic technique or decreased handwashing. Increased patient census alone may increase the risk of crosstransmission of nosocomial infections. As hospitals proceed with costcontainment efforts, the effect of fluctuations in patient census and nurse staffing on patient outcomes needs evaluation.

From: Archibald LK, Manning ML, Bell LM, Banerjee S, Jarvis WR. Patient density, nurse-to-patient ratio and nosocomial infection risk in a pediatric cardiac intensive care unit. Pediatr Infect Dis J 1997;16:1045-1048. 